Fikroh : Jurnal Pemikiran dan Pendidikan Islam

Volume. 13, Number. 1, Januari 2020

p-ISSN : 2087-7501, e-ISSN : 2715-4459

Hlm : 44-56

Journal Home Page : https://jurnal.stai-alazharmenganti.ac.id/index.php/fikroh

\title{
HUBUNGAN DISIPLIN BELAJAR DAN MINAT BELAJAR DENGAN HASIL BELAJAR PENDIDIKAN AGAMA ISLAM PADA MATERI KEBEBASAN MENGEMUKAKAN PENDAPAT SISWA KELAS VII DI MTS NEGERI 1 SIDOARJO KABUPATEN SIDOARJO
}

\author{
Ahmad \\ IAI Al Khoziny Buduran, Sidoarjo, Indonesia \\ Ahmad@,email.com
}

\begin{abstract}
This study aims to determine the relationship of learning discipline and learning interest with learning outcomes of islamic religious education. This study uses a survey method, namely: Research conducted on large and small populations, but the data studied is sample data taken from the population, so it is found relative events, distribution, and relationships between sociological and psychological variables ". The following are the results of the study: (1) Learning Discipline (X1) is positively and strongly correlated with Islamic Religious Education Learning Outcomes $(Y)$ on the subject of freedom of expression in MTs Negeri 1 Sidoarjo Sidoarjo Regency, with a correlation value of 0.947. (2) Interest in Learning (X2) is positively and strongly related to Learning Outcomes of Islamic Education $(Y)$ on the subject of freedom of expression in MTs Negeri 1 Sidoarjo, Sidoarjo Regency, with a correlation value of 0.935. (3) Learning Discipline (X1) and Learning Interest (X2) jointly have a positive and very strong relationship with Islamic Education Learning Outcomes (Y) on the freedom of expression of material in MTs Negeri 1 Sidoarjo Sidoarjo, Sidoarjo Regency, with a correlation value of 0.95 .
\end{abstract}

Keywords: Discipline Learning; Interest in learning; Learning Outcomes

\begin{abstract}
Abstrak
Penelitian ini bertujuan untuk mengetahui hubungan disiplin belajar dan minat belajar dengan hasil belajar pendidikan agama islam. Penelitian ini menggunakan metode survey, yaitu: Penelitian yang dilakukan pada populasi besar maupun kecil, tetapi data yang dipelajari adalah data sampel yang diambil dari populasi tersebut, sehingga ditemukan kejadian-kejadian relatif, distribusi, dan hubunganhubungan antar variabel sosiologis maupun psikologis." Berikut ini merupakan hasil penelitian: (1) Disiplin Belajar (X1) berhubungan positif dan sangat kuat
\end{abstract}


dengan Hasil Belajar Pendidikan Agama Islam (Y) pada materi kebebasan mengemukakan pendapat di MTs Negeri 1 Sidoarjo Kabupaten Sidoarjo, dengan nilai korelasi sebesar 0 ,947. (2) Minat Belajar (X2) berhubungan positif dan sangat kuat terhadap Hasil Belajar Pendidikan Agama Islam (Y) pada materi kebebasan mengemukakan pendapat di MTs Negeri 1 Sidoarjo Kabupaten Sidoarjo, dengan nilai korelasi sebesar 0,935. (3) Disiplin Belajar (X1) dan Minat Belajar (X2) secara bersama- sama berhubungan positif dan sangat kuat terhadap Hasil Belajar Pendidik an Agama Islam (Y) pada materi kebebasan mengemukakan pendapat di MTs Negeri 1 Sidoarjo Kabupaten Sidoarjo, dengan nilai korelasi sebesar 0,951.

Kata kunci: Disiplin Belajar, Minat belajar, Hasil Belajar

\section{A. Pendahuluan}

Berdasarkan observasi dan wawancara yang penulis lakukan di MTs Negeri 1 Sidoarjo dengan salah satu guru Pendidikan Agama Islam kelas VII, diketahui bahwa hasil belajar Pendidikan Agama Islam kelas VII masih rendah. Siswa cenderung kurang aktif dalam kegiatan pembelajaran hampir pada semua mata pelajaran terutama pada mata Pendidikan Agama Islam dan hasil belajar Pendidikan Agama Islam siswa tergolong pelajaran rendah. Hal ini ditunjukkan dari hasil ujian semester tahun pelajaran 2015-2017. Dengan Kriteria Ketuntasan Minimal (KKM) yang ditetapkan oleh sekolah yakni $70 .{ }^{1}$

Siswa yang memiliki disiplin belajar baik di sekolah maupu di rumahnya akan menunjukan kesiapannya dalam mengikuti pelajaran, datang tepat waktu, memperhatikan guru, menyelesaikan tugas tepat waktu dan memiliki kelengkapan belajar yang dapat menunjang proses belajarnya selama di sekolah maupun di rumah. ${ }^{2}$ Oleh karena itu kita tahu bahwa disiplin belajar merupakan salah satu hal yang penting dalam menunjang hasil belajar siswa yang baik. Dalam hal ini hendaknya guru dan orang tua memahami kodisi peserta didik untuk lebih memperhatikan kedisiplinan belajarnya. Selain dukungan dari orang tua, siswa juga harus diberi nasehat dan motivasi dari guru agar mau belajar dengan disiplin baik di sekolah maupun di rumah. ${ }^{3}$ Seperti dikutip dalam buku Peran Disiplin

\footnotetext{
${ }^{1}$ Heruman, Model Pembelajaran Pendidikan Agama Islam Di Smp (Bandung: Remaja Rosdakarya, 2008)

2 Sardiman, Dasar-Dasar Evaluasi Pendidikan Edisi 2 (Jakarta: Bumi Aksara, 2012)

3 Miftahul, Huda, Model-Model Pengajaran Dan Pembelajaran: Isu-Isu Metodis Dan Paragdigmatis (Yogyakarta: Pustaka Pelajar, 2014)
} 


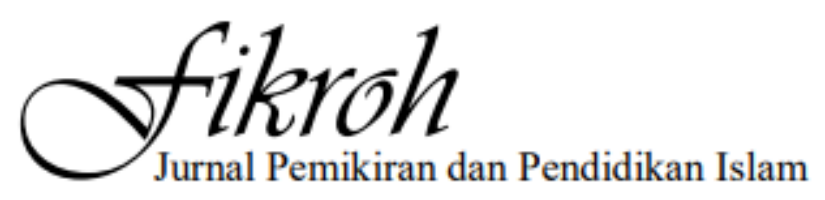

Hubungan Disiplin Belajar...

pada Perilaku dan Hasil Siswa, Tulus berpendapat bahwa disiplin terjadi dan terbentuk sebagai hasil dan dampak proses pembinaan cukup panjang yang dilakukan sejak dari dalam keluarga dan berlanjut dalam pendidikan di sekolah. Keluarga dan sekolah menjadi tempat penting bagi pengembangan disiplin seseorang. ${ }^{4}$ Dengan kondisi ini, membuat hasil belajar siswa terutama mata pelajaran Pendidikan Agama Islam masih kurang memuaskan. ${ }^{5}$

\section{B. Metode Penelitian}

Penelitian ini menggunakan metode survey, yaitu: "Penelitian yang dilakukan pada populasi besar maupun kecil, tetapi data yang dipelajari adalah data sampel yang diambil dari populasi tersebut, sehingga ditemukan kejadian-kejadian relatif, distribusi, dan hubungan-hubungan antar variabel sosiologis maupun psikologis." Dengan metode tersebut akan dibangun suatu teori yang dapat berfungsi untuk menjelaskan, meramalkan dan mengontrol suatu gejala, terutama yang didasarkan pada paradigma positivisme yang bersifat logico-hypotheco-verifikatif. ${ }^{6}$ Penggunaan konsep dan teori yang relevan serta pengkajian terhadap hasil-hasil penelitian yang mendahului guna menyusun hipotesis merupakan aspek logika (logico-hypotetico), sedangkan pemilihan metode penelitian, menyusun instrumen, mengumpulkan data dan analisisnya adalah merupakan aspek metodologi untuk memverifikasikan hipotesis yang diajukan.

\section{Hasil dan Pembahasan}

Hasil belajar adalah perubahan tingkah laku seseorang setelah mengikuti proses belajar dan pembelajaran sesuai dengan tujuan pendidikan. Hasil belajar sendiri diartikan sebagai perubahan yang mengakibatkan manusia berubah dalam sikap dan tingkah lakunya. Aspek perubahan itu mengacu kepada taksonomi tujuan pengajaran yang dikembangkan oleh Bloom, Simpson dan Harrow mencakup aspek kognitif, afektif dan psikomotorik. Melalui belajar seseorang dapat dapat menemukan cara-cara baru untuk dapat melakukan sesuatu dan dengan belajar seseorang dapat mengatasi

\footnotetext{
${ }^{4}$ Ahmad Susanto, Teori Belajar Dan Pembelajaran Di Sekolah Dasar (Jakarta: Prenadamedia Group, 2014)

5 Bsnp, Panduan Penyusunan Kurikulum Tingkat Satuan Pendidikan Jenjang Pendidikan Dasar Dan Menengah (Jakarta: Bsnp, 2006)

6 Didik Supriyanto, "Modeling: Jurnal Program Studi Pgmi” Vol.2, No.2 (2015). Http://Jurnal.Stitnualhikmah.Ac.Id/Index.Php/Modeling/Article/View/67.
}

Volume. 13, Number. 1, Januari 2020 
rintangan dalam menghadapi masalah kehidupan serta dapat mudah menyesuaikan diri dengan situasi baru, artinya dengan pengetahuan danperkembangan otak (kognitif) yang maksimal ia dapat dengan mudah untuk beradaptasi. ${ }^{7}$

Hintzman seperti dikutip Syah mengungkapkan bahwa belajar adalah suatu perubahan yang terjadi dalam diri organisme, manusia dan hewan, disebabkan oleh pengalaman yang dapat mempengaruhi tingkah laku tersebut, sedangkan menurut Cronbach dalam bukunya Educational Psychologi yang dikutip oleh Suryabrata menyatakan bahwa: "learning is shown by a change in behavior asa result of experience." Maksudnya adalah bahwa belajar ditunjukan oleh suatu perubahan didalam perilaku sebagai Hasil pengalaman, jadi bila siswa tanpa pengalaman tidak dikat akan belajar. Purwanto menyatakan bahwa "berhasil atau tidaknya proses pembelajaran dipengaruhi oleh dua faktor, yaitu: faktor individual dan faktor sosial. Faktor individual adalah faktor yang ada pada organisme itu sendiri yang meliputi kematangan/pertumbuhan, kecerdasan, latihan, minat dan faktor pribadi. Sementara faktor sosial yaitu faktor yang ada di luar individu yang meliputi: sekolah atau keadaan sekolah tangga, siswa dan cara mengajarnya, alat-alat mengajar, lingkungan dan kesempatan yang tersedia, serta minat sosial.",

Hasil belajar dapat dilihat dengan adanya perubahan-perubahan tingkah laku yang secara teknisi dinyatakan dalam suatu pernyataan verbal melalui tujuan instruksional. Susanto menyatakan bahwa: "Keterampilan atau perilaku baru tersebut dapat berupa pengertian, kecakapan, sikap penghargaan dan sebagainya. ${ }^{9}$ Keterampilan tersebut diperoleh melalui suatu proses belajar, proses belajar bukan saja mempengaruhi orang agar mengubah cara bertindak dan bersikap, melainkan menciptakan atau menyediakan suatu kondisi yang merangsang, memberi pengarahan, dorongan dan bimbingan untuk memperoleh pengetahuan, keterampilan, sikap serta nilai, yang mengakibatkan perubahan tingkah laku.” Dengan kata lain bahwa Hasil belajar adalah nilai aktif dari seorang peserta

\footnotetext{
${ }^{7}$ Isjoni, Pembelajaran Kooperatif Meningkatkan Kecerdasan Komunikasi Antar Peserta Didik (Jakarta: Sinar Grafika, 2013)

${ }^{8}$ Faridhatul Khasanah, Pengarub Penerapan Strategi Pembelajaran Aktif Tipe Teka-Teki Silang Terbadap Hasil Belajar Siswa Kelas Iv Sd Negeri 4 Metro Timur (Universitas Lampung, 2014)

${ }^{9}$ Djamarah Dan Aswan Zain, Strategi Belajar Mengajar (Jakarta: Pt Rineka Cipta, 2013)
} 
didik yang dinilai melalui teknik evaluasi dan dapat digunakan sebagai petunjuk seberapa jauh materi pelajaran telah dikuasai oleh peserta didik. ${ }^{10}$ Sementara itu belum mengklasifikasikan kategori Hasil belajar kedalam tiga kawasan yang disebut domain yaitu: domain kognitif adalah segala kecakapan yang berkenaan dengan pikiran manusia; domain afektif adalah kecakapan yang ada hubungannya dengan perasaaan manusia, menyangkut nilai, sikap, estetika dan sebagainya; domain psikimotorik adalah kemampuan-kemampuan yang tampak, karena sangat kaitan dengan gerakan yang bersumber yang bersumber pada keterampilan, gerakan otot maupun tubuh manusia." Sedangkan Hasil belajar adalah kemampuan yang diperoleh berdasar proses belajar meliputi kecakapan untuk mengkomunikasikan pengetahuan secara verbal yang dikategorikan sebagai informasi verbal; kecakapan dalam bertindak melalui penilaian terhadap suatu stimulus yang dikategorikan sebagai sikap; kecakapan membedakan dan memahami konsep maupun aturan serta dapat memecahkan masalah, yang dikategorikan sebagai keterampilan intelektual; kecakapan mengelola dan mengembangkan proses berfikir melalaui pemahaman, analisis, dan sistematis, yang dikategorikan sesbagai keterampilan yang kognitif; kecakapan yang diperlihatkan secara cepat, tepat, dan lancar melalui gerakan anggota tubuh yng dikategorikan sebagai keterampilan motorik. ${ }^{11}$ Menurut Sardiman menyatakan bahwa: "Setiap proses belajar yang dialami oleh siswa akan menghasilkan hasil belajar. Pada proses pembelajaran, guru memegang peranan dan tanggung jawab yang besar dalam rangka membantu meningkatkan keberhasilan siswa dalam belajar. Pada setiap proses pembelajaran di sekolah setiap siswa berharap mendapatkan hasil belajar yang optimal. Agar memperoleh hasil belajar yang optimal proses pembelajaran harus dilakukan dengan sadar dan sengaja serta terorganisasi dengan baik."

Besarnya variasi perubahan Hasil Belajar Pendidikan Agama Islam (Y) pada materi kebebasan mengemukakan pendapat yang mampu dijelaskan oleh Disiplin Belajar (X1) yang dimasukkan dalam model persamaan regresi sederhana mencapai sekitar 89,70\%, sedangkan sisanya sebesar $10,30 \%$ dipengaruhi dari variabel bebas lain yang tidak dimasukkan ke dalam model persamaan regresi sederhana dan tidak diteliti, sehingga

\footnotetext{
${ }^{10}$ Sugiyono, Metode Penelitian Pendidikan (Bandung: Alfabeta, 2013)

${ }^{11}$ Kasmadi Dan Nia Siti Sunariah, Panduan Modern Penelitian Kuantitatif (Bandung: Alfabeta, 2014)
} 
Disiplin Belajar (X1) memiliki kemampuan cukup tinggi menjelaskan Hasil Belajar Pendidikan Agama Islam (Y) pada materi kebebasan mengemukakan pendapat. Besarnya variasi perubahan Hasil Belajar Pendidikan Agama Islam (Y) pada materi kebebasan mengemukakan pendapat yang mampu dijelaskan oleh Minat Belajar (X2) yang dimasukkan dalam model persamaan regresi sederhana mencapai sekitar $87,40 \%$, sedangkan sisanya sebesar 12,60\% dipengaruhi dari variabel bebas lain yang tidak dimasukkan ke dalam model persamaan regresi sederhana dan tidak diteliti, sehingga Minat Belajar (X2) memiliki kemampuan tinggi menjelaskan Hasil Belajar Pendidikan Agama Islam (Y) pada materi kebebasan mengemukakan. ${ }^{12}$ Besarnya variasi perubahan Hasil Belajar Pendidikan Agama Islam (Y) pada materi kebebasan mengemukakan pendapat yang mampu dijelaskan oleh Disiplin Belajar (X1) dan Minat Belajar (X2) secara bersama-sama yang dimasukkan dalam model persamaan regresi ganda mencapai sekitar $90,40 \%$, sedangkan sisanya sebesar $9,60 \%$ dipengaruhi dari variabel bebas lain yang tidak dimasukkan ke dalam model persamaan regresi ganda dan tidak diteliti, sehingga Disiplin Belajar (X1) dan Minat Belajar (X2) secara bersama-sama memiliki kemampuan sangat tinggi menjelaskan Hasil Belajar Pendidikan Agama Islam (Y) pada materi kebebasan mengemukakan pendapat. ${ }^{13}$ Diantara variabelvariabel bebas dalam penelitian ini, maka variabel bebas yang sangat dominan mempengaruhi Hasil Belajar Pendidikan Agama Islam (Y) pada materi kebebasan mengemukakan pendapat siswa kelas VII di MTs Negeri 1 Sidoarjo Kabupaten SIDOARJO adalah Disiplin Belajar (X1). ${ }^{14}$

\section{Sub Bab Pembahasan Disiplin Dan Minat Belajar}

\section{a. Displin belajar}

Harlock menyatakan bahwa konsep populer dari "disiplin" adalah sama dengan "hukuman." Menurut konsep ini, disiplin hanya digunakan bila anak melanggar peraturan dan perintah yang diberikan guru, guru atau orang dewasa yang berwenang mengatur kehidupan bermasyarakat tempat anak itu tinggal.

\footnotetext{
${ }^{12}$ Muhammad Fathurrohman, Model-Model Pembelajaran Inovatif (Yogyakarta: Ar-Ruzz, 2015)

${ }^{13}$ Suharsini Arikunto, Prosedur Penelitian Suatu Pendekatan Praktik Edisi Revisi Vd (Jakarta: Pt Renika Cipta, 2006)

${ }^{14}$ Zainal Aqib, Penelitian Tindakan Kelas Untuk Sd, Slb, Tk (Bandung: Yrama Widya, 2010)
} 
Disiplin merupakan cara masyarakat mengajar anak perilaku moral yang disetujui kelompok." Disiplin adalah suatu bentuk ketaatan terhadap aturan, baik tertulis maupun tidak tertulis yang telah ditetapkan. Moenir menyatakan bahwa disiplin adalah kontrol dalam mematuhi aturan baik yang dibuat oleh diri sendiri maupun di luar diri baik sekolah, lembaga pendidikan, masyarakat, bernegara, maupun beragama. ${ }^{15}$

Disiplin dalam sekolah sebenarnya berkenaan dengan perumusan anggota sekolah tentang yang benar dan tidak benar, yang berkaitan dengan peraturan dan harapan yang telah ditentukan berhubungan dengan situasi dan tingkah laku tertentu." Pertumbuhan disiplin dalam sekolah secara timbal balik memanfaatkan kehidupan beragama dan pancaran norma-norma untuk mengambil keputusan dalam berbagai situasi kehidupan dalam suatu kompleksitas masyarakat yang terus menerus berubah karena adanya peningkatan ilmu pengetahuan dan teknologi, maupun karena perkembangan kemajuan masyarakat itu sendiri. ${ }^{16}$

Buku Pola Asuh Guru, mengatakan tanggung jawab guru adalah mengupayakan agar anak berdiasiplin diri untuk melaksankan hubungan dengan Tuhan yang menciptakannya, dirinya sendiri, sesama manusia, dan lingkungan alam dan makhluk hidup lainnya berdasarkan nilai moral. Menurut Imelda individu yang memiliki kedisiplinan belajarakan menunjukkan ciri sebagai berikut:

1) Orang yang disiplin terntunya memiliki jadwal kegiatan dan mempunyai waktu belajar yang teratur.

2) Orang yang hidup disiplin akan belajar sedikit demi sedikit (mancicil) secara berkesinambungan.

3) Mengerjakan tugas sesuai dengan jadwal atau rencana, sehingga tugas selesai tepat pada waktunya.

4) Belajar di tempat dan suasan yang mendukung menurutnya. ${ }^{17}$

Berdasarkan uraian teori diatas peneliti berasumsi, disiplin dalam sekolah atau sekolah berorientasi pada kewajiban guru dalam mendidik anak dengan

${ }^{15}$ Kokom Komalasari, Pembelajaran Kontekstual: Konsep Dan Aplikasi (Bandung: Pt Refika Aditama, 2010)

${ }^{16}$ Masitoh, Strategi Pembelajaran (Jakarta: Departemen Agama Republik Indonesia, 2009)

${ }^{17}$ Jumanta Hamdayana, Model Dan Metode Pembelajaran Kreatif Dan Berkaraketer, 2015) 
menanamkan disiplin pribadi sejak dini, salah satunya yaitu takwa terhadap Tuhan Yang Maha Esa. Agama sebagai dasar disiplin dalam sekolah untuk proses pembentukan pribadi merupakan satu cita-cita yang terdapat dalam butir pertama dari kelima butir tujuan pendidikan, sesuai urutannya adalah ketaqwaan terhadap Tuhan Yang Maha Esa, peningkatan budi pekerti yang luhur, peningkatan kepribadian, peningkatan pengetahuan dan keterampilan, serta cinta kepada bangsa dan tanah air. Disiplin belajar adalah ajaran perilaku mengenai kegiatan belajar yang sudah disetujui oleh kelompok sekolah untuk diterapkan di dalam sekolah yang dipatuhi oleh seluruh anggota sekolah. ${ }^{18}$

\section{b. Minat Belajar}

Minat belajar terdiri dari dua kata yakni minat dan belajar, dua kata ini berbeda arti, untuk itu penulis akan mendefinisikan satu-persatu, sebagai berikut:

1) Minat menurut kamus besar bahasa Indonesia adalah kecenderungan hati yang tinggi terhadap suatu gairah keinginan.

2) Minat menurut Mahfudz Shalahuddin adalah perhatian yang mengandung unsur-unsur perasaan. ${ }^{19}$

individu yang memiliki kedisiplinan belajar akan menunjukkan ciri sebagai berikut:

1) Orang yang disiplin terntunya memiliki jadwal kegiatan dan mempunyai waktu belajar yang teratur.

2) Orang yang hidup disiplin akan belajar sedikit demi sedikit (mancicil) secara berkesinambungan.

3) Mengerjakan tugas sesuai dengan jadwal atau rencana, sehingga tugas selesai tepat pada waktunya.

4) Belajar di tempat dan suasan yang mendukung menurutnya. ${ }^{20}$

Berdasarkan uraian teori diatas peneliti berasumsi, disiplin dalam sekolah atau sekolah berorientasi pada kewajiban guru dalam mendidik anak dengan menanamkan disiplin pribadi sejak dini, salah satunya yaitu takwa terhadap Tuhan

18 Abdul Majid, Strategi Pembelajaran (Bandung: Remaja Rosdakarya, 2015)

${ }^{19}$ Kurniasih Dan Berlin Sani, Ragam Pengembangan Model Pembelajaran (Kata Pena, 2016)

${ }^{20}$ Udin Winataputra S., Minat Belajar (Jakarta: Universitas Terbuka, 2008) 
Yang Maha Esa. ${ }^{21}$ Agama sebagai dasar disiplin dalam sekolah untuk proses pembentukan pribadi merupakan satu cita-cita yang terdapat dalam butir pertama dari kelima butir tujuan pendidikan, sesuai urutannya adalah ketaqwaan terhadap Tuhan Yang Maha Esa, peningkatan budi pekerti yang luhur, peningkatan kepribadian, peningkatan pengetahuan dan keterampilan, serta cinta kepada bangsa dan tanah air. ${ }^{22}$ Disiplin belajar adalah ajaran perilaku mengenai kegiatan belajar yang sudah disetujui oleh kelompok sekolah untuk diterapkan di dalam sekolah yang dipatuhi oleh seluruh anggota sekolah. ${ }^{23}$

\section{Sub Bab Pembahasan Hubungan Disiplin, Minat, Dan Hasil Belajar}

\section{a. Hubungan Disiplin belajar dengan Hasil Belajar}

Bertolak dari pemikiran bahwa dengan kedisiplinan, maka rasa malas dan rasa enggan dapat teratasi sehingga hal ini memungkinkan siswa untuk mencapai hasil belajar yang memuaskan. Dalam hal ini peneliti juga menyadari tidak hanya faktor kedisiplinan saja yang berhubungan atau mempengaruhi hasil belajar, akan tetapi faktor lain minat belajar juga mempengaruhi hasil belajar siswa. Dari berbagai pendapat dapat diduga bahwa siswa yang memiliki sikap disiplin yang tinggi dalam belajar di sekolah dan di rumah, akan dapat meraih hasil belajar yang baik Apalagi didukung oleh minat belajar yang membaik maka hasil belajar Pendidikan Agama Islam pada materi kebebasan mengemukakan pendapat kelas VII di MTs Negeri 1 Sidoarjo akan meningkat. Sehingga diduga disiplin belajar dan minat belajar mempunyai hubungan dengan hasil belajar. ${ }^{24}$

\section{b. Hubungan Minat Belajar dengan Hasil Belajar}

Minat belajar adalah suatu keinginan atau hasrat yang disebabkan oleh dorongan intrinsik maupun ekstrinsik. Minat belajar diukur dari faktor kebutuhan belajar, perhatian, keuletan, kontstribusi dan cita-cita Minat merupakan kecenderungan rasa suka yang tinggi terhadap sesuatu. Jika siswa merasa senang

\footnotetext{
${ }^{21}$ Suwangsih, Erna, Tiurlina, Model Pembelajaran Pendidikan Agama Islam (Bandung: Upi Press, 2006)

22 Supriyanto, Didik. "Pengaruh Pendekatan Saintifik Pada Pembelajaran Seni Budaya Dan Prakarya Terhadap Capaian Akademis Siswa Kelas Iv Di Mi Salafiyah Syafi' Iyah Ii Klinterejo Sooko Mojokerto." Nazhruna: Jurnal Pendidikan Islam 2, No.2 (2019)

${ }^{23}$ Rusman, Model-Model Pembelajaran Mengembangkan Profesionalisme Guru (Jakarta: Rajagrafindo Persada, 2014)

${ }^{24}$ Eko Prayoga Jaya, Pengaruh Model Pembelajaran Kooperatif Stad Terhadap Hasil Belajar Pendidikan Agama Islam Siswa Kelas Viii Di Smp Negeri 1 Tulang Bawang Tengah Tabun Pelajaran 2015/2016 (Universitas Lampung, 2016)
} 
dalam belajar, maka ia akan dengan cepat mengerti dan memahami materi yang diberikan guru. Dalam hal ini minat merupakan salah satu faktor yang dapat mempengaruhi hasil belajar. Ketika seorang siswa memiliki minat belajar, ia akan menunjukkan pada beberapa indikator seperti memiliki perasaan yang senang, merasa tertarik dengan suatu pembelajaran, memberikan perhatian yang tinggi, dan juga keterlibatan yang aktif dalam kegiatan pembelajaran. Jika minat belajar yang besar maka hasil belajarnya akan tinggi, sebaliknya minat belajar yang kurang akan menghasilkan hasil belajar yang rendah. Sehingga diduga minat belajar mempunyai hubungan dengan hasil belajar siswa kelas VII di MTs Negeri 1 Sidoarjo. ${ }^{25}$

\section{c. Hubungan Disiplin Belajar dan minat belajar (secara bersama-sama) dengan Hasil Belajar.}

Bertolak dari pemikiran bahwa dengan kedisiplinan, maka rasa malas dan rasa enggan dapat teratasi sehingga hal ini memungkinkan siswa untuk mencapai hasil belajar yang memuaskan. Dalam hal ini peneliti juga meny adari tidak hanya faktor kedisiplinan saja yang berhubungan atau mempengaruhi hasil belajar, akan tetapi faktor lain minat belajar juga mempengaruhi hasil belajar siswa. Dari berbagai pendapat dapat diduga bahwa siswa yang memiliki sikap disiplin yang tinggi dalam belajar di sekolah dan di rumah, akan dapat meraih hasil belajar yang baik Apalagi didukung oleh minat belajar yang membaik maka hasil belajar Pendidikan Agama Islam pada materi kebebasan mengemukakan pendapat kelas VII di MTs Negeri 1 Sidoarjo akan meningkat. Sehingga diduga disiplin belajar dan minat belajar mempunyai hubungan dengan hasil belajar. ${ }^{26}$

\section{Simpulan}

Disiplin Belajar (X1) berhubungan positif dan sangat kuat dengan Hasil Belajar Pendidikan Agama Islam (Y) pada materi kebebasan mengemukakan pendapat di MTs

\footnotetext{
${ }^{25}$ Hari Satyawan, Pengaruh Pembelajaran Kooperatif Tipe Jigsaw Terhadap Prestasi Belajar Matematika Siswa Pada Materi Pokok. Kubus Dan Balok Kelas Vii Mts Assyafi' Iyah Gondang Tulunggagung Tabun Ajaran 2010/2011. Stain Tulungagung (2016)

${ }_{26}$ M. Ngalim Purwanto, Prinsip-Prinsip Dan Teknik Evaluasi Pengajaran (Bandung: Pt Remaja Rosdakarya Offset, 2008)
} 
Negeri 1 Sidoarjo Kabupaten SIDOARJO, dengan nilai korelasi sebesar 0,947. ${ }^{27}$ Besarnya variasi perubahan Hasil Belajar yang mampu dijelaskan oleh Disiplin Belajar (X1) mencapai sekitar 89,70\%, sedangkan sisanya sebesar 10,30\% dipengaruhi dari variabel bebas lain yang tidak dimasukkan ke dalam model persamaan regresi sederhana dan tidak diteliti, sehingga Disiplin Belajar (X1) memiliki kemampuan cukup tinggi dalam menjelaskan Hasil Belajar Pendidikan Agama Islam (Y) pada materi kebebasan mengemukakan pendapat. ${ }^{28}$

Minat Belajar (X2) berhubungan positif dan sangat kuat terhadap Hasil Belajar Pendidikan Agama Islam (Y) pada materi kebebasan mengemukakan pendapat di MTs Negeri 1 Sidoarjo Kabupaten SIDOARJO, dengan nilai korelasi sebesar 0,935. ${ }^{29}$ Besarnya variasi perubahan Hasil Belajar Pendidikan Agama Islam (Y) pada materi kebebasan mengemukakan pendapat yang mampu dijelaskan oleh Minat Belajar (X2) mencapai sekitar $87,40 \%$, sedangkan sisanya sebesar 12,60\% dipengaruhi dari variabel bebas lain yang tidak dimasukkan ke dalam model persamaan regresi sederhana dan tidak diteliti, sehingga Minat Belajar (X2) memiliki kemampuan tinggi dalam menjelaskan Hasil Belajar Pendidikan Agama Islam (Y) pada materi kebebasan mengemukakan pendapat.

Disiplin Belajar (X1) dan Minat Belajar (X2) secara bersama-sama berhubungan positif dan sangat kuat terhadap Hasil Belajar Pendidikan Agama Islam (Y) pada materi kebebasan mengemukakan pendapat di MTs Negeri 1 Sidoarjo Kabupaten Sidoarjo, dengan nilai korelasi sebesar 0,951. Besarnya variasi perubahan Hasil Belajar Pendidikan Agama Islam (Y) pada materi kebebasan mengemukakan pendapat yang mampu dijelaskan oleh Disiplin Belajar (X1) dan Minat Belajar (X2) secara bersama-sama mencapai sekitar 90,40\%, sedangkan sisanya sebesar 9,60\% dipengaruhi dari variabel bebas lain yang tidak dimasukkan ke dalam model persamaan regresi ganda dan tidak diteliti, sehingga Disiplin Belajar (X1) dan Minat Belajar (X2) secara bersama-sama memiliki kemampuan sangat tinggi dalam menjelaskan Hasil Belajar Pendidikan Agama Islam (Y) pada materi kebebasan mengemukakan pendapat.

\footnotetext{
${ }^{27}$ A. Muri Yusuf, Metode Penelitian Kuantitatif, Kualitatif, Dan Penelitian Gabungan (Jakarta: Kencana, 2014)

${ }^{28}$ Muhamamad Ali, Gunawan, Statistik Penelitian Pendidikan (Yogyakarta: Parama Publishing, 2013)

${ }^{29}$ Syofian Siregar, Statistik. Parametrik. Untuk Penelitian Kuantitatif (Jakarta: Remaja Rosdakarya, 2013)
} 


\section{E. Daftar Pustaka}

Aqib, Zainal. Penelitian Tindakan Kelas Untuk Sd, Slb, Tk. Bandung: Yrama Widya, 2010.

Arikunto, Suharsini. Prosedur Penelitian Suatu Pendekatan Praktik (Edisi Revisi Vd). Jakarta: Pt Renika Cipta, 2006.

Bsnp. Panduan Penyusunan Kurikulum Tingkat Satuan Pendidikan Jenjang Pendidikan Dasar Dan Menengah. Jakarta: Bsnp, 2006

Djamarah Dan Zain, Aswan. Strategi Belajar Mengajar. Jakarta: Pt Rineka Cipta, 2013.

Fathurrohman, Muhammad. Model-Model Pembelajaran Inovatif. Yogyakarta: Ar-Ruzz, 2015.

Gunawan, Muhamamad Ali. Statistik Penelitian Pendidikan. Yogyakarta: Parama Publishing, 2013.

Hamdayana, Jumanta. Model Dan Metode Pembelajaran Kreatif Dan Berkarakter, 2015.

Heruman. Model Pembelajaran Pendidikan Agama Islam Di Smp. Bandung: Remaja Rosdakarya, 2008.

Huda, Miftahul. Model-Model Pengajaran Dan Pembelajaran: Isu-Isu Metodis Dan Paragdigmatis. Yogyakarta: Pustaka Pelajar, 2014.

Isjoni. Pembelajaran Kooperatif Meningkatkan Kecerdasan Komunikasi Antar Peserta Didik. Jakarta: Sinar Grafika, 2013.

Jaya, Eko Prayoga. Pengaruh Model Pembelajaran Kooperatif Stad Terhadap Hasil Belajar Pendidikan Agama Islam Siswa Kelas Viii Di Smp Negeri 1 Tulang Bawang Tengah Tabun Pelajaran 2015/2016. Universitas Lampung, 2016.

Kasmadi Dan Sunariah, Nia Siti. Panduan Modern Penelitian Kuantitatif. Bandung: Alfabeta, 2014.

Khasanah, Faridhatul. Pengaruh Penerapan Strategi Pembelajaran Aktif Tipe Teka-Teki Silang Terbadap Hasil Belajar Siswa Kelas Iv Sd Negeri 4 Metro Timur. Universitas Lampung, 2014.

Komalasari, Kokom. Pembelajaran Kontekstual: Konsep Dan Aplikasi. Bandung: Pt Refika Aditama, 2010.

Kurniasih Dan Sani, Berlin. Ragam Pengembangan Model Pembelajaran. Kata Pena, 2016.

Majid, Abdul. Strategi Pembelajaran. Bandung: Remaja Rosdakarya, 2015.

Masitoh. Strategi Pembelajaran. Jakarta: Departemen Agama Republik Indonesia, 2009.

Purwanto, M. Ngalim. Prinsip-Prinsip Dan Teknik Evaluasi Pengajaran. Bandung: Pt Remaja Rosdakarya Offset, 2008.

Rusman. Model-Model Pembelajaran Mengembangkan Profesionalisme Guru. Jakarta: Rajagrafindo Persada, 2014. 
Sardiman. Dasar-Dasar Evaluasi Pendidikan Edisi 2. Jakarta: Bumi Aksara, 2012.

Satyawan, Hari. Pengarub Pembelajaran Kooperatif Tipe Jigsaw Terhadap Prestasi Belajar Matematika Siswa Pada Materi Pokok Kubus Dan Balok Kelas Vii Mts Assyafi' Iyah Gondang Tulunggagung Tahun Ajaran 2010/2011. Stain Tulungagung. Accessed Oktober 14, 2016.

Siregar, Syofian. Statistik Parametrik Untuk Penelitian Kuantitatif. Jakarta: Remaja Rosdakarya, 2013.

Sugiyono. Metode Penelitian Pendidikan. Bandung: Alfabeta, 2013.

. Undang-Undang Nomor 20 Tahun 2003 Tentang Sistem Pendidikan Nasional, 2009.

. Metode Penelitian Kuantitatif Kualitatif Dan R\&DD. Bandung: Alfabeta, 2014.

Metode Penelitian Pendidikan Pendekatan Kuantitatif Kualitatif. Bandung: Alfabeta, 2016.

Suprijono, Agus. Cooperative Learning Teori Dan Aplikasi Paikem (Revisi). Yogyakarta: Pustaka Pelajar, 2015.

Supriyanto, Didik. "Pengaruh Pendekatan Saintifik Pada Pembelajaran Seni Budaya Dan Prakarya Terhadap Capaian Akademis Siswa Kelas Iv Di Mi Salafiyah Syafi' Iyah Ii Klinterejo Sooko Mojokerto.” Ną̧bruna: Jurnal Pendidikan Islam Vol.2, No.2 (2019).

Supriyanto, Didik. Modeling: Jurnal Program Studi Pgmi Vol.2, No.2 (2015). Http://Jurnal.Stitnualhikmah.Ac.Id/Index.Php/Modeling/Article/View/67.

Susanto, Ahmad. Teori Belajar Dan Pembelajaran Di Sekolah Dasar. Jakarta: Prenadamedia Group, 2014.

Suwangsih, Erna, Tiurlina. Model Pembelajaran Pendidikan Agama Islam. Bandung: Upi Press, 2006.

Tim Penyusun. Permendiknas Nomor 22 Tabun 2006 Tentang Standar Isi.. Jakarta: Depdiknas, 2006.

Winataputra, S. Udin. Minat Belajar. Jakarta: Universitas Terbuka, 2008.

Yusuf, A. Muri. Metode Penelitian Kuantitatif, Kualitatif, Dan Penelitian Gabungan. Jakarta: Kencana, 2014. 